EVALUATION OF THE IMPLEMENTATION OF PSAK 71 CONCERNING

EXPECTED CREDIT LOSS ON THE CONSOLIDATED FINANCIAL

STATEMENTS OF THE COMPANY PT WASKITA KARYA (PERSERO) TBK

\title{
EVALUATION OF THE IMPLEMENTATION OF PSAK 71 CONCERNING EXPECTED CREDIT LOSS ON THE CONSOLIDATED FINANCIAL STATEMENTS OF THE COMPANY PT WASKITA KARYA (PERSERO) TBK
}

\author{
Kiki Fernando Perpetua Oroh ${ }^{1)^{*}}$, Lintje Kalangi ${ }^{2)}$, Sintje Rondonuwu ${ }^{3)}$ \\ 1, 2,3 Departement of Accounting, Sam Ratulangi University, Indonesia
}

\begin{abstract}
The Financial Accounting Standards Board Institute of Indonesia Chartered Accountants issued guidelines for responding to the COVID-19 pandemic on entity financial reports, namely the application of PSAK 71 concerning expected credit losses which was effective January 1 , 2020. This study aims to:(1) determine the application of PSAK 71 regarding expected credit losses at PT. Waskita Karya Tbk (2) the impact of the application of the PSAK 71 rules on the company's financial statements of PT. Waskita Karya Tbk. The method of analysis used in this thesis research is descriptive method in which the aim of each data is collected to be analyzed then draws a conclusion and the type of research used is descriptive qualitative.The results obtained that the company has implemented PSAK 71 in the 2020 reporting period with the principle of 12-month expected loss so that it has an impact on a decrease in retained earnings by $24.2 \%$ of the total decline in the company's retained earnings in 2020 and also has an impact on a decrease in total equity by 20, 47\% of the total equity decline in 2020.
\end{abstract}

Keywords: Evaluation, Application, Expected Credit Loss

\section{INTRODUCTION}

One way to increase a company's profits is through credit sales. Credit sales must be regulated in accounts receivable management. In addition, sales on credit will provide a stable value for assets and business capital so that the company will not experience losses if there is a decline in sales. Therefore, trade receivables are one of the important assets in the company that must be managed as well as possible so that the company gets profits and good management. Financial instruments are assets in the form of cash or contract documents that provide access to a person to receive or other financial instruments and various evidence of capital ownership of an entity or company. In connection with this study, ECL affects trade receivables which are an important part of assets in financial instruments.

Researchers are interested in conducting research on the application of PSAK 71 which discusses how to apply expected credit losses to companies. Where PSAK 71 is an amendment to the complicated PSAK 50, 55 and 60 taken from IAS No. 39. PSAK 71 is derived from IFRS No. 9 issued by the IASB to ease the difficulties of the previous IAS, as well as facilitate the handling of financial instruments due to the crisis in the US and Europe from 2008 to 2011.

Along with the change from PSAK 55 to PSAK 71, the COVID-19 phenomenon has occurred which has resulted in a decrease in the company's financial assets. The Financial Accounting Standards Board of the Indonesian Institute of Accountants (DSAK IAI) has issued a publication based on a decision regarding the instructions for preparing financial reports for entities based on the principles of Financial Accounting Standards (SAK), which aims to realize that the uncertainty caused by the COVID-19 pandemic can significantly affect the judgment of financial statements. company. Implementation of PSAK 71 Financial Instruments, which was initially implemented on January 1, 2020. This publication provides

*Corresponding author. Email address: kikifernando771@ gmail.com 


\section{AFEBI Economic and Finance Review (AEFR)}

\section{Volume 6, No 2 (2021)}

clarification and guidance in considering whether the Covid-19 pandemic may affect the calculation of expected credit loss (ECL) on the date of initial application of PSAK 71 on January 1, 2020. Measurement of ECL in PSAK 71 requires entities to measure ECL in a manner that reflects reasonable and supportable information available without undue cost or effort at the reporting date regarding past events, current conditions and estimates of future economic conditions.

Researchers have the desire to discuss the application of PSAK 71 regarding ECL in the company PT Waskita Karya Tbk because this company is a company engaged in the construction industry, manufacturing, rental services, agency services, investment, and EPC where this company is a large company owned by state-owned enterprises (BUMN) with large total assets. The company applies PSAK 71 regarding KKE in the company's consolidated financial statements which will be the object of research from the application of PSAK 71 and determine the impact on the company's financial statements.

\section{LITERATURE STUDY}

\section{Accounts Receivable}

Herry (2017: 150) Receivables refer to a number of invoices that will be received by the company (generally in the form of cash) from other parties, either as a result of delivering goods and services on credit (for customer receivables consisting of trade receivables and allowing notes receivable). Loans (for employee receivables, debtor receivables, and interest receivables), as well as as a result of overpayments to other parties (for tax receivables). In accounting, receivables must be properly classified and presented in the balance sheet. Receivables that are estimated to be collectible within one year or less from the balance sheet date should be presented as current assets, while those with more than one year should be presented and classified as investments or other assets. Receivables arise from credit sales transactions. Sales on credit are made to increase sales volume (revenue). Only sales on credit have the risk of uncollectible accounts. Uncollectible receivables are classified into costs which are known as the cost of bad debts.

According to Gitosudarmo (2012: 82) with the implementation of credit sales which then lead to receivables, the company is actually inseparable from risk coverage in the form of costs. The costs incurred as a result of receivables are:

a. Bad debt write-off costs the risk of uncollectible a certain amount of receivables will be included as the cost of doubtful accounts which will later be written off. Therefore it needs to be taken into account at each period.

b. The cost of collecting receivables With the existence of receivables, receivable collection activities arise which will incur a fee known as the cost of collecting receivables.

c. Administrative costs for receivables, administrative activities are required which will incur costs.

d. Cost of sources of funds with the occurrence of receivables, funds from inside and outside the company are needed to maintain them. These funds are required for funding sources.

There are two methods of reserve for receivables losses, namely the reserve method and the direct write-off method. According to Baridwan, there are 2 methods of recording receivable losses, namely:

a. Direct deletion method

This method assumes that losses on receivables are recognized and recorded as an expense if they cannot be collected. Uncollectible receivables are obtained after the company receives official notification that the debtor is declared bankrupt by the competent authority or the debtor himself notices that he is no longer able to pay off his obligations. 


\section{EVALUATION OF THE IMPLEMENTATION OF PSAK 71 CONCERNING EXPECTED CREDIT LOSS ON THE CONSOLIDATED FINANCIAL STATEMENTS OF THE COMPANY PT WASKITA KARYA (PERSERO) TBK}

b. Backup method

According to Mardiasmo (2011: 96) "The reserve method is a loss that is made as a result of uncollectible receivables which must be a burden for the period in which the decision to grant credit is carried out". The reserve method is used when the usual receivable losses are quite large. According to Yusup (2009: 56) three important things that need to be considered in the application of the reserve method are as follows :

1) Losses on bad debts are determined through estimates and matched with sales in the same accounting period as the period in which the sale occurred.

2) The estimated amount of receivables that will not be accepted is recorded by debiting the Accounts Receivable Loss and crediting the Allowance for Receivables Loss account.

3) Actual receivable losses are recorded by debiting the Allowance for Receivables account and crediting the Accounts Receivable account when a receivable is written off from the books.

\section{Financial Instruments}

In PSAK 50 (revised 2010) par. 07, a financial instrument is defined as any contract that adds to the value of an entity's financial assets and financial liabilities or other entity's equity instruments. Likewise, IAS 32 (2009) par. 11 defines "a financial instrument is any contract that gives rise to a financial asset of one entity and a financial liability or equity instrument of another entity". Prior to adopting IAS 39, the term financial instrument in PSAK 50 (1998) par. 06 are referred to as "securities" which have the definition of securities, namely debt acknowledgments, commercial securities, shares, bonds, proof of debt, and units of participation in collective investment contracts.

IFRS 7 (Wiley, 2011) mendefinisikan instrumen keuangan "any contract that evidences a residual interest in the assets of an entity after deducting all its liabilities". While PSAK 50 (2010) par. 07 defines a financial instrument (equity instrument) as any contract that provides a residual interest in the assets of an entity after deducting all of its liabilities. A derivative instrument (derivative instrument) is a financial instrument or other contract that has 3 characteristics, namely the value changes as a result of changes in variables that have been found, does not require an initial net investment or requires a small initial net investment, and is settled on a certain date in the future.

\section{PSAK 71 Financial Instruments - Expected Credit Losses}

Credit losses are the difference between all contractual cash flows due to the entity under the contract and all cash flows expected to be received by the entity (ie all cash shortages), discounted by the original effective interest rate (or the credit-adjusted effective interest rate for financial assets, purchased or derived from deteriorating financial assets). Expected credit loss is a weighted average of credit losses with each occurrence of default risk being weighted. Under the generally accepted approach, at each financial reporting date, an entity measures:

a. 12-month ECL allowance (which in practice is often referred to as being in stage 1) for a financial instrument, ie the risk of loss over the next 12 months if the credit risk of the financial instrument has not increased significantly since initial recognition [PSAK 71 paragraph 5.5.5]; or

b. ECL lifetime allowance, i.e. the risk of loss over the remaining expected life of the financial instrument, if the credit risk of the financial instrument has increased significantly since initial recognition [PSAK 71 paragraph 5.5.3].

Thus, PSAK 71 requires that the lifetime ECL be recognized if there is a significant increase in credit risk (SICR) on a financial instrument. Assessment of SICR requires an entity to assess changes in the risk of default that arise over the expected life of a financial instrument 


\section{AFEBI Economic and Finance Review (AEFR)}

\section{Volume 6, No 2 (2021)}

[paragraph 5.5.9] of PSAK 71. In assessing whether SICR has occurred or in measuring ECL, the entity considers all reasonable and supportable information including future information [PSAK 71 paragraph 5.5.9].

\section{Previous research results:}

a. Arya Prabu Rizal, 2020, Motives and Obstacles of Banks Implementing Early Implementation of PSAK No. 71. Variables and indicators : PSAK No. 71, Early Implementation, Institutional Theory, Institutional Logic, Coercive, Mimetic, and Normative Isomorphism. This research uses a case study strategy with a mixed-method research approach (a combination of qualitative and quantitative methods becomes a separate study). This study finds that early adopters are banks with government, foreign and mixed ownership types. In addition, the authors also found that the motive for making a decision whether to do or not to implement PSAK No. This condition is dominated early by isomorphism conditions that arise (normative isomorphism) due to pressure or demands from professionals who are considered correct. This study also finds that there are differences (heteregoneity) in the behavior of actors and institutions in each commercial bank which are influenced by multiple logics, namely regulatory logics and banking logics.

b. MP Wibowo, 2020, Analysis of the Application of PSAK 71 in the Presentation of Allowance for Impairment Losses and Financial Performance of Banking Companies. Variables and indicators : PSAK 71, Impairment Loss, CAMEL, Financial Instruments. This study uses secondary data obtained in the form of annual financial reports containing audit reports and other additional information. Analyzing CTBC Bank CKPN is in accordance with PSAK 71 or not and analyzing the company's financial performance. The results of this study indicate that CTBC Bank has implemented PSAK 71 regarding CKPN properly and the calculation is in accordance with the transition of PSAK 71. The decrease in the Bank's CAMEL value was 3.33 due to a decrease in net income and total assets. However, as of December 31, 2018, the company has succeeded in increasing the CAMEL value to 85.55 and obtained a healthy status from Bank Indonesia.

\section{RESEARCH METHODOLOGY}

This type of research is a qualitative research with a descriptive approach. Qualitative methods are used in this study because it requires a study that is not extensive but is in-depth representation based on the phenomena that occur in the object of research. The object of qualitative research develops itself. Then the instrument in qualitative research is the researcher himself, so that researchers are required to have the ability in the field of theory and broad insight in order to analyze and construct situations that occur in research to be clearer and more meaningful (Sugiyono, 2016:88). Data collection will be carried out using the document study method. The data used is secondary data taken from the official page of PT Waskita Karya (Persero) Tbk (http://www.waskita.co.id). According to Sugiyono (2016: 99) data analysis is an activity after the data is available for research. For the qualitative descriptive analysis method, the researcher will process the data starting with grouping the data, then summarizing and presenting the data, then doing calculations based on the theoretical study used to answer the problem and produce research data and discussion.

\section{RESULT AND DISCUSSION \\ Result}

\section{Overview of Accounting Policies at PT Waskita Karya}

The company PT Waskita Karya Tbk has a measurement basis in the preparation of consolidated financial statements, namely the historical cost concept. The measurement exception occurs in the company's fixed asset accounts which have been revalued (revalued) in 2000, investments in certain securities which are carried at fair value or carried using the 


\section{EVALUATION OF THE IMPLEMENTATION OF PSAK 71 CONCERNING EXPECTED CREDIT LOSS ON THE CONSOLIDATED FINANCIAL STATEMENTS OF THE COMPANY PT WASKITA KARYA (PERSERO) TBK}

equity method and inventories which are stated at the lower of the cost or net realizable value. values. There are several overviews of the application of PSAK 71 to companies, namely (1) Identification and Measurement of Impairment Losses. In the application of PSAK 71 the Company PT Waskita Karya Tbk requires loss reserves to be recognized at 12-month Expected Credit Loss (ECL) or expected lifetime ECL credit losses. Using the probability of default (PD) matrix model which is done by discounting using the effective interest rate. (2) 12 Months Expected Credit Loss, in PT Waskita Karya Tbk company, expected credit losses will be recognized at the time of initial recognition of financial instruments and companies that will represent cash shortages over the life of the asset arising from the possibility of future defaults within 12 months after the reporting date. The company will apply this basis for calculating expected credit losses until later if there is a significant increase in credit risk on the affected instrument or the instrument has decreased credit value. (3) Significant Increase in Credit Risk, If the company's financial assets experience a significant increase in credit risk since initial recognition, then expected credit losses are recognized for default events that may occur throughout the life of the asset. (4) Exposure to Impaired Credit or Default, Financial assets in the company will be impaired (or defaulted) if the asset is at least in arrears more than 420 days after the reporting date.

\section{Movements in Allowance for Impairment Losses on Receivables}

Based on the Notes to the Company's Consolidated Financial Statements, PT Waskita Karya has an allowance for impairment losses on receivables and is calculated based on the type of receivables. The following is a breakdown of the allowance for impairment losses by type of receivables :

a. Accounts Receivable - Net

1) Accounts receivable construction services

Based on the details of the balance of construction services trade receivables, there are mutations in the allowance for impairment losses on construction services trade receivables in the following table:

Table 1: Mutations of Allowance for Impairment Losses on Accounts Receivable

\begin{tabular}{|l|r|c|}
\hline & 2020 & 2019 \\
\cline { 2 - 3 } & $\mathrm{Rp}$ & $\mathrm{Rp}$ \\
\hline Beginning Balance & $(635.254 .521 .734)$ & $(636.940 .928 .722)$ \\
\hline Adjustment on Application of PSAK 71 & $(178.483 .644 .577)$ & -- \\
\hline Addition of PSAK 71 for Current Year & $(219.480 .060 .520)$ & -- \\
\hline Addition & -- & $(16.390 .803 .888)$ \\
\hline Recovery & 564.159 .048 & 27.730 .099 .738 \\
\hline Reclassification & -- & $(9.733 .888 .862)$ \\
\hline Ending Balance & $(1.032 .654 .067 .783)$ & $(635.254 .521 .734)$ \\
\hline
\end{tabular}

Source: Consolidated Financial Statements of PT Waskita Karya 2020

Based on table 1, there is an additional allowance for impairment losses on construction services trade receivables originating from adjustments to the application of PSAK 71 which has an impact on retained earnings of Rp178,438,644,577; and the addition of the current year amounting to Rp219,480,060,520; next is the recovery value for the allowance for impairment of trade receivables for construction services amounting to Rp564,159,048; In 2019, the value of the increase in losses from construction services trade receivables amounted to Rp16,309,803,888; and the recovery amounted to $\mathrm{Rp} 27,730,099,738$; So that there is an increase in the allowance 


\section{AFEBI Economic and Finance Review (AEFR)}

\section{Volume 6, No 2 (2021)}

for impairment losses on construction services in 2020 amounting to Rp397,399,546,049; or 61.5\% from the previous year 2019.

2) Account receivable

Based on the details of the balance of trade receivables, there are mutations in the allowance for impairment losses in the following table :

Tabel 2: Mutation of Allowance for Impairment Losses on Trade Receivables

\begin{tabular}{|c|c|c|}
\hline & 2020 & 2019 \\
\hline & $\mathrm{Rp}$ & $\mathrm{Rp}$ \\
\hline Beginning Balance & $(28.872 .695 .637)$ & $(29.520 .292 .803)$ \\
\hline Adjustment on Application of PSAK 71 & $(242.396 .767 .336)$ & -- \\
\hline Addition of PSAK 71 for Current Year & $(219.480 .060 .520)$ & -- \\
\hline Addition & -- & $(16.812 .787 .100)$ \\
\hline Recovery & -- & 17.460 .384 .266 \\
\hline Reclassification & -- & -- \\
\hline Ending Balance & $(464.034 .578 .173)$ & $(28.872 .695 .637)$ \\
\hline
\end{tabular}

Source: Consolidated Financial Statements of PT Waskita Karya 2020.

Based on table 2 in 2020, there was an additional allowance for impairment losses on trade receivables originating from adjustments to the application of PSAK 71 which had an impact on retained earnings of Rp.242,396,767,336; and the addition of the current year amounting to Rp192,765,115,200; there is no recovery on allowance for impairment of trade receivables. In 2019, the value of the increase in losses from construction services trade receivables amounted to Rp16,812,787,100; and the recovery amounted to $\mathrm{Rp} 17,460,384,266$; So that there is an increase in the allowance for impairment losses on construction services in 2020 amounting to Rp435,161,882,536; from the previous year 2019.

b. Retention Receivables - Net

Based on the details of the retention receivable balance, there are mutations in the allowance for impairment losses on receivables in the following table :

Tabel 3: Mutation in Allowance for Impairment Losses Retention Receivables

\begin{tabular}{|l|r|r|}
\hline \multirow{2}{*}{ Beginning Balance } & \multicolumn{1}{|c|}{2020} & \multicolumn{1}{c|}{2019} \\
\cline { 2 - 3 } & $\mathrm{Rp}$ & \multicolumn{1}{c|}{$\mathrm{Rp}$} \\
\hline Adjustment on Application of PSAK 71 & $(166.844 .256 .392)$ & $(207.630 .738 .137)$ \\
\hline Recovery of PSAK 71 for Current Year & 139.459 .619 .607 & -- \\
\hline Addition & -- & $(3.908 .000 .000)$ \\
\hline Recovery & 13.202 .076 .908 & 30.326 .535 .615 \\
\hline Reclassification & -- & 14.367 .946 .130 \\
\hline Ending Balance & $(251.094 .359 .648)$ & $(166.844 .256 .392)$ \\
\hline
\end{tabular}

Source: Consolidated Financial Statements of PT Waskita Karya 2020

Based on table 3 in 2020, there is an additional allowance for impairment losses on retention receivables originating from adjustments to the application of PSAK 71 which has an impact on retained earnings of $\mathrm{Rp} 236,911,799,771$; and the addition of the current year amounting to Rp139,459,619,607; next is the recovery value of the allowance for impairment of retention receivables amounting to Rp13,202,076,908; In 2019, the additional value for retention receivable losses amounted to $\mathrm{Rp3}, 908,000,000$; and the recovery amounted to Rp30,326,535,615; So that there is an increase in the allowance for impairment losses on retention values in 2020 amounting to $\mathrm{Rp} 84,250,103,256$; or $66.4 \%$ from the previous year 2019. 


\section{EVALUATION OF THE IMPLEMENTATION OF PSAK 71 CONCERNING EXPECTED CREDIT LOSS ON THE CONSOLIDATED FINANCIAL STATEMENTS OF THE COMPANY PT WASKITA KARYA (PERSERO) TBK}

c. Other Receivables - Net

Based on the details of the balance of other receivables, there are mutations in the allowance for impairment losses on receivables in the following table :

Table 4: Mutation in Allowance for Impairment Losses on Other Receivables

\begin{tabular}{|l|r|r|}
\hline & \multicolumn{1}{|c|}{2020} & \multicolumn{1}{c|}{2019} \\
\cline { 2 - 3 } & $\mathrm{Rp}$ & \multicolumn{1}{c|}{$\mathrm{Rp}$} \\
\hline Beginning Balance & $(87.191 .858 .614)$ & $(116.525 .751 .779)$ \\
\hline Adjustment on Application of PSAK 71 & $(246.115 .546 .517)$ & -- \\
\hline Recovery of PSAK 71 for Current Year & $(9.806 .646 .846)$ & -- \\
\hline Recovery & -- & 29.816 .404 .375 \\
\hline Reclassification & 1.698 .958 .666 & $(482.511 .210)$ \\
\hline Ending Balance & $(341.415 .093 .311)$ & $(87.191 .858 .614)$ \\
\hline
\end{tabular}

Source: Consolidated Financial Statements of PT Waskita Karya 2020

Based on table 4 in 2020, there is an additional allowance for impairment losses on retention receivables originating from adjustments to the application of PSAK 71 which has an impact on retained earnings of Rp246,115,546,517; and the addition of the current year amounting to Rp9,806,646,846; there is no addition and recovery of allowance for impairment losses on other receivables. In 2019, there was no change in other receivable losses and the recovery amounted to $\mathrm{Rp} 29,816,404,375$; So that there is an increase in the reserve for impairment losses on retention values in 2020 amounting to Rp254,223,234,697; from the previous year 2019.

d. Gross Amount Due From Customers

Based on the details of the gross invoice balance to service users, there is a mutation in the reserve for impairment losses on gross invoices to service users - the non-current part in the following table :

Table 5 Mutation of Allowance for Impairment Losses Gross Amount Due from Customers

\begin{tabular}{|l|r|r|}
\hline & \multicolumn{1}{|c|}{2020} & \multicolumn{1}{c|}{2019} \\
\cline { 2 - 3 } & \multicolumn{1}{c|}{$\mathrm{Rp}$} & $\mathrm{Rp}$ \\
\hline Beginning Balance & $(380.887 .754 .974)$ & $(373.477 .461 .097)$ \\
\hline Adjustment on Application of PSAK 71 & $(1.701 .669 .670 .534)$ & -- \\
\hline Recovery of PSAK 71 for Current Year & 205.540 .073 .153 & -- \\
\hline Addition & -- & $(23.463 .718 .514)$ \\
\hline Recovery & 71.727 .018 .512 & 20.204 .970 .695 \\
\hline Reclassification & 5.724 .688 .193 & $(4.151 .546 .058)$ \\
\hline Ending Balance & $(1.799 .565 .645 .650)$ & $(380.887 .754 .974)$ \\
\hline
\end{tabular}

Source: Consolidated Financial Statements of PT Waskita Karya 2020

Based on table 5 in 2020, there is an additional allowance for impairment losses on gross receivables to service users originating from adjustments to the application of PSAK 71 which has an impact on retained earnings of Rp. 1,701,669,670,534; and recovery for the current year amounting to Rp205,540,073,153; and recovery of allowance for impairment losses amounting to $\mathrm{Rp} 71,727,018,512$; In 2019, the additional value for allowance for impairment losses was Rp.23,463,718,514; and the recovery amounted to Rp20,204,970,695; So that there is an increase in the allowance for impairment losses on gross invoices to service users in 2020 amounting to Rp1,418,677,890,676; from the previous year 2019. 


\section{AFEBI Economic and Finance Review (AEFR)}

\section{Volume 6, No 2 (2021)}

Based on the calculation of the allowance for impairment losses above, it can be seen that there is an additional reserve due to the adjustment of PSAK 71, so that it has an impact on retained earnings which will affect the financial statements of the company PT. Waskita Karya. For this reason, this data will serve as a guide in the discussion, namely the impact of PSAK 71 on the company's consolidated financial statements.

There is a risk of $A / R$ loss to related parties rather than third parties where for each category of receivables the amount of risk reserve for related parties is higher than that of third parties.

\section{Identification and Measurement of Impairment Losses}

In the application of PSAK 71 the Company PT. Waskita Karya Tbk requires that the allowance for losses be recognized at the amount of the 12-month expected credit loss (ECL) or the expected credit loss over the life of the financial asset (lifetime ECL). Lifetime ECL itself is an expected credit loss arising from all possible default events throughout the expected life of a financial instrument, in contrast to the 12 month ECL which is a portion of the expected credit loss arising from possible default events within 12 months after the reporting date. This ECL loss is recognized for all of the company's trade receivables and financial guarantee instruments which are classified as hold to collect/hold to collect and sell and have SPPI cash flows. The Company does not recognize expected credit losses for equity instruments designated as FVOCI (fair value through other comprehensive income).

\section{Discussion}

\section{Application of PSAK 71 Concerning Expected Credit Losses in Companies}

At the beginning of 2020 the company has made adjustments to the retained earnings of Rp. 2,390,286,004,446; originating from an increase in allowance for impairment losses on financial instruments. The following will summarize the accounts were affected by the decline ECL derived from 1 Reports of the consolidated financial position of the company at the beginning of the implementation of January 1, 2020 , the following table 6 for details :

Table 6: Account Details Affected by ECL Decrease

\begin{tabular}{|c|c|c|c|c|c|c|}
\hline & Sebelum KKE & KKE & Setelah KKE & & & \\
\hline Piutang Usaha - Bersih & & & - & $\begin{array}{r}\text { Accounts Receivable - } \\
\text { Net }\end{array}$ & $\%$ & \\
\hline Pihak Berelasi & 1.085 .899 .931 .009 & (123.243.080.914) & 962.656 .850 .095 & Related Parties & 5,16 & \multirow{14}{*}{$100 \%$} \\
\hline Pihak Ketiga & 2.469 .994 .551 .718 & (297.637.330.999) & 2.172 .357 .220 .719 & Third Parties & 12,45 & \\
\hline Piutang Retensi - Bersih & & & 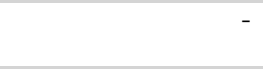 & $\begin{array}{r}\text { Retention Receivables - } \\
\mathrm{Net}\end{array}$ & & \\
\hline Pihak Berelasi & 1.461 .470 .561 .988 & $(39.822 .752 .002)$ & 1.421 .647 .809 .986 & Related Parties & 1,67 & \\
\hline Pihak Ketiga & 321.656 .594 .689 & (197.089.047.769) & 124.567 .546 .920 & Third Parties & 8,25 & \\
\hline $\begin{array}{l}\text { Piutang Lain-lain lancar - } \\
\text { Bersih }\end{array}$ & & & - & $\begin{array}{r}\text { Other Current } \\
\text { Receivable-Net }\end{array}$ & & \\
\hline Pihak Berelasi & 3.961 .228 .866 .682 & $(95.513 .646 .098)$ & 3.865 .715 .220 .584 & Related Parties & 4,00 & \\
\hline Pihak Ketiga & 4.437 .931 .030 .282 & $(150.601 .900 .419)$ & 4.287 .329 .129 .863 & Third Parties & 6,30 & \\
\hline $\begin{array}{l}\text { Tagihan Bruto Kepada } \\
\text { Pengguna Jasa }\end{array}$ & & & - & $\begin{array}{l}\text { Gross Amount Due } \\
\text { From Customers }\end{array}$ & & \\
\hline Bagian Lancar & & & - & Current Portion & & \\
\hline Pihak Berelasi & 11.475 .684 .609 .873 & $(876.823 .076 .255)$ & 10.598 .861 .533 .618 & Related Parties & 36,68 & \\
\hline Pihak Ketiga & 2.695 .490 .949 .143 & $(824.846 .594 .279)$ & 1.870 .644 .354 .864 & Third Parties & 34,51 & \\
\hline Aset Pajak Tangguhan & 1.542 .424 .572 & 215.291 .424 .289 & 216.833 .848 .861 & Deffered Tax Assets & $(9,01)$ & \\
\hline TOTAL & 27.910 .899 .519 .956 & $(2.390 .286 .004 .446)$ & 25.520 .613 .515 .510 & & $(8,56)$ & \\
\hline
\end{tabular}

Source: Data processed, 2021 


\section{EVALUATION OF THE IMPLEMENTATION OF PSAK 71 CONCERNING EXPECTED CREDIT LOSS ON THE CONSOLIDATED FINANCIAL STATEMENTS OF THE COMPANY PT WASKITA KARYA (PERSERO) TBK}

Based on table 6, it can be seen that the account that has the highest expected credit loss reserves is in Gross Receivables to Service Users of 36.68\% from Related Parties and 34.51\% from Third Parties, while the lowest expected credit loss reserves are in Deferred Tax Assets of $9.01 \%$. From the application of this reserve, it is assumed that the company has assessed the reserves as well as possible to avoid future risk (default), by taking appropriate action because the company also applies the value of the reserve for losses retrospectively where there is a separate assessment of the parties involved.

\section{Impact of PSAK 71 regarding Expected Credit Losses on Consolidated Financial Statements ending December 31, 2020}

The implementation of PSAK 71 regarding ECL has the following impact on the company's financial statements :

a. Retained Earnings

Based on the application of this expected credit loss reserve, it affects the company's retained earnings of PT Waskita Karya (Persero) Tbk. Which is reflected in the table of retained earnings calculation below :

Table 7 : Retained Earnings PT. Waskita Karya Persero (Tbk)

\begin{tabular}{|c|c|c|}
\hline & 2020 & 2019 \\
\hline & $\mathrm{Rp}$ & $\mathrm{Rp}$ \\
\hline \multicolumn{3}{|l|}{ Appropriated } \\
\hline Beginning Balance & 1.672 .393 .928 .212 & 1.583 .494 .837 .349 \\
\hline Addition on Reserved Fund & 59.707 .469 .060 & 88.899.090.863 \\
\hline Ending Balance & 1.732.101.397.272 & 1.672.393.928.212 \\
\hline \multicolumn{3}{|l|}{ Unappropiated } \\
\hline Beginning Balance & 8.561 .015 .893 .115 & 8.763 .909 .422 .956 \\
\hline $\begin{array}{l}\text { Profit Attributable to Owners of } \\
\text { the Parent Entity }\end{array}$ & $(7.378 .553 .582 .119)$ & 938.142 .364 .887 \\
\hline $\begin{array}{l}\text { Adjustment for Implementation of } \\
\text { PSAK } 71\end{array}$ & $(2.390 .286 .004 .446)$ & - \\
\hline Devidend & $(46.907 .502 .471)$ & $(990.709 .507 .966)$ \\
\hline $\begin{array}{l}\text { Allocation to General Reserve } \\
\text { Remeasurement of Defined }\end{array}$ & $(59.707 .469 .060)$ & $(88.899 .090 .863)$ \\
\hline Benefit Plants & - & $(61.427 .295 .899)$ \\
\hline $\begin{array}{l}\text { Adjustment for Changes } \\
\text { Ownership in Subsidiaries }\end{array}$ & 7.923 .172 .505 & - \\
\hline Ending Balance & $(1.306 .515 .492 .476)$ & 8.561.015.893.115 \\
\hline
\end{tabular}

Source : Data processed, 2021

Based on table 7 when compared to 2019 it can be seen that the company experienced a decrease in retained earnings that have not been determined by $115.26 \%$ or worth

$\mathrm{Rp} 9,867,531,385,591$; and the total loss from the decline in retained earnings that has not been determined for use in 2020 is - Rp9,875,454,558,096; It can also be seen that the account that is very influential on the decline in retained earnings in 2020 is the Profit Attributable to Owners of the Parent Entity where in the previous year (2019) the company received a balance of Rp.938,142,364,887; decreased in 2020 by -Rp7,387,553,582,119; (74.8\% of losses in 2020) followed by the determination of the expected credit loss allowance (PSAK 71) causing the company to experience a decrease in retained earnings by - Rp2,390,286,004,446; $(24.2 \%$ of 2020 loss), dividend distribution of - Rp46,907,502,471; (0.4\% of losses in 2020), and the establishment of general reserves of - Rp59,707,469,060; (0.6\% of 2020 loss).

b. Changes in Company Equity

The following in table 8 is a detailed data on the consolidated financial statement changes in equity processed by researchers in the application of PSAK 71 regarding expected credit losses : 


\section{AFEBI Economic and Finance Review (AEFR)}

Volume 6, No 2 (2021)

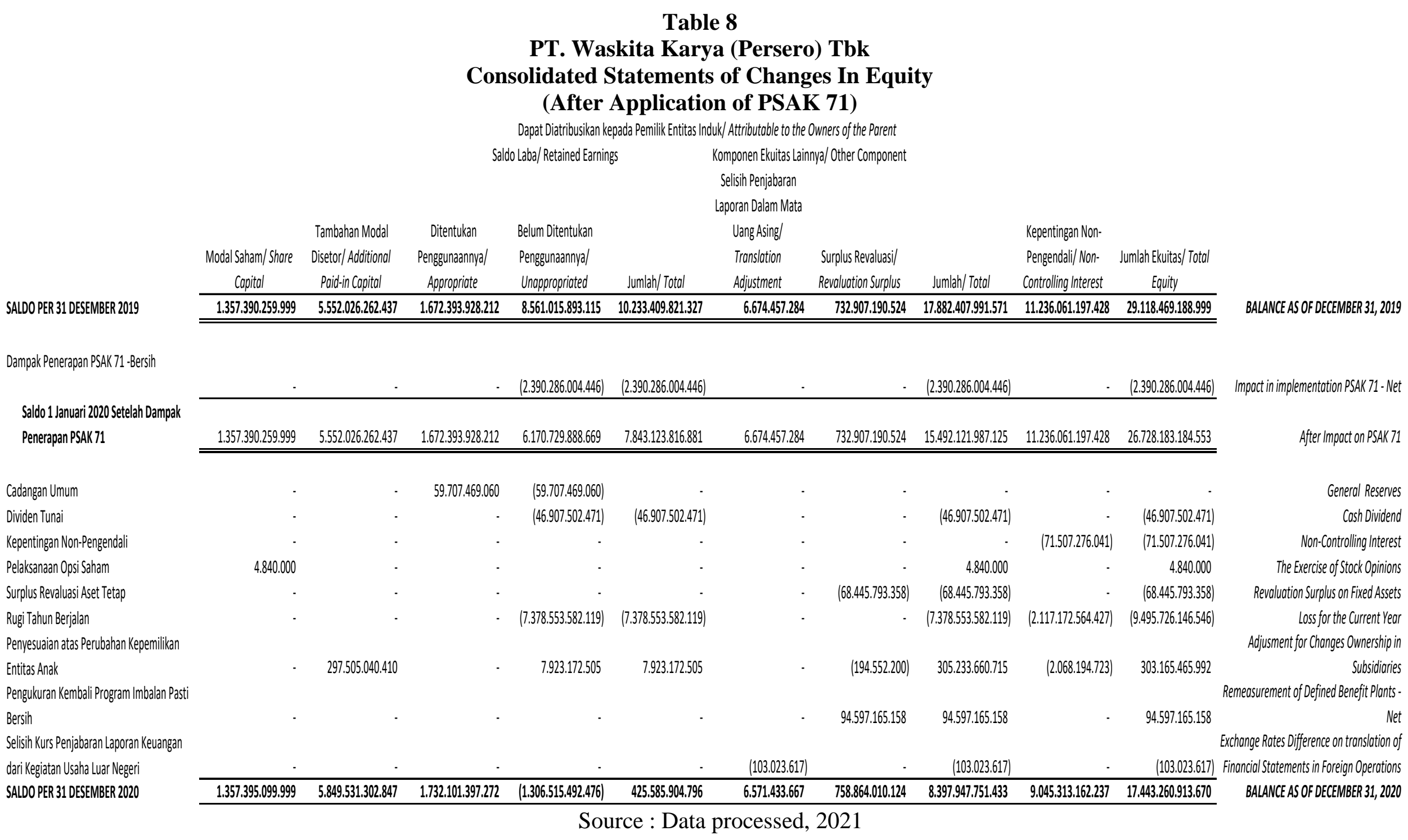




\section{EVALUATION OF THE IMPLEMENTATION OF PSAK 71 CONCERNING EXPECTED CREDIT LOSS ON THE CONSOLIDATED FINANCIAL STATEMENTS OF THE COMPANY PT WASKITA KARYA (PERSERO) TBK}

In table 8 the statement of changes in equity after the application of PSAK 71 shows that the equity balance as of December 31, 2020 amounted to Rp17,443,260,913,670; When compared with the company's equity balance in the reporting period of December 31, 2019 which amounted to Rp29,118,469,188,999; it can be concluded that the company experienced a decrease in equity by $40 \%$ or Rp. $11,675,208,275,329$; The decrease in equity was also influenced by an increase in the expected credit loss reserves amounting to $\mathrm{Rp} 2,390,286,004,446$; or $20.47 \%$ of the total decline in equity during 2020 . The researcher believes that in addition to the expected credit loss reserves that have a significant impact, it also occurs because the attribution to the owners of the parent entity is very low, as seen in the figure in table 8 Retained Earnings shows a minus value.

c. Notes to Consolidated Financial Statements (amendments to PSAK 71)

Previously the company used PSAK 55 as the basis for measuring allowance for impairment losses, so DSAK IAI issued a new rule that replaced PSAK 55 into PSAK 71 which was effective January 1, 2020, with the main changes in the table below :

\section{Table 9: Comparison of PSAK 71 and PSAK 55}

\begin{tabular}{|c|c|c|c|}
\hline No. & Description & PSAK 71 & PSAK 55 \\
\hline 1 & Model Type & Expected Loss & Incurred Loss \\
\hline 2 & Number of Models & One & Several \\
\hline 3 & Scope & Expanded & Expanded \\
\hline 4 & $\begin{array}{l}\text { Financial Instrument } \\
\text { Investment }\end{array}$ & $\begin{array}{l}\text { No impairment is } \\
\text { recognized for equity } \\
\text { instruments }\end{array}$ & $\begin{array}{l}\text { Impairment is recognized } \\
\text { for investments in equity } \\
\text { instruments classified as } \\
\text { AFS* }\end{array}$ \\
\hline 5 & Consideration & Increase & Increase \\
\hline
\end{tabular}

Source : IAI global, 2020

In table 9, changes in the application of PSAK 71 have introduced a measurement model using the expectation of 12 months after the reporting date in determining the allowance for impairment losses on financial assets. The difference also appears in number 4 regarding investment in financial instruments where previously in PSAK 55 an impairment was recognized for investments in equity instruments classified as available-to-sale (AFS) financial assets, it changed after the change in the rules in PSAK 71 which mandated no no impairment is recognized for the financial instrument. Based on an assessment of the business model and contractual cash flows, this new arrangement for the classification and measurement of financial instruments has no impact on the carrying amount of financial assets and liabilities as of January 1, 2020.

\section{PSAK 71 perspective on the company}

Based on the discussion that has been discussed, it can be seen that the application of ECL can be said to be fair because it determines the amount of future losses that considers the amount of losses based on the method used and consideration of historical, present and forward looking losses. In addition, the determination of ECL is very significant because there is an increase in the amount of reserves that make the company describe losses to its financial statements. 


\section{AFEBI Economic and Finance Review (AEFR)}

\section{Volume 6, No 02 (2021)}

\section{CONCLUSION}

The application of PSAK 71 has been carried out by the company in accordance with the guidelines and adjusting the transition rules so that the company can conduct a retrospective assessment by looking at the cumulative impact. So, based on his assessment of the business model of PSAK 71 regulations, it can be classified and measured in terms of expected credit losses for 12 months which result in a decrease in the value of financial assets in the company. This application is suitable to be applied to this company because it has a large financial asset value along with the amount of receivables from related parties and third parties in each category of receivables which creates a loss reserve. The impact that occurs on the company due to the application of PSAK 71 Expected Credit Loss makes the retained earnings decrease and changes in the company's total equity, so that the company suffers a significant loss when compared to the retained earnings obtained by the company in 2019 and the company's total equity in 2019.

\section{References}

Baridwan, Zaki. 2011. Intermediate Accounting Edisi 8. Yogyakarta : BPFE.

Exposure Draft. (2016). Pernyataan standar akunansi keuangan instrumen keuangan: pengakuan dan pengukuran PSAK No.71. Ikatan Akuntan Indonesia. www.iaiglobal.or.id

Gitosudarmo Indriyo. 2012. Manajemen Pemasaran. edisi kedua, cetakan kedua. Penerbit : BPFE - Yogyakarta.

Hery. (2016). Pengantar Akuntansi (Comprehensif Edition). Jakarta: PT Grasindo.

Ikatan Akuntan Indonesia. (2017). Pernyataan Standar Akuntansi Keuangan (PSAK) Nomor 1 Tentang Penyajian Laporan Keuangan. Jakarta : IAI

Ikatan Akuntansi Indonesia. 2014. PSAK 55 (Revisi 2014) : Instrumen Keuangan : Pengakuan dan Pengukuran. Jakarta : IAI

Kieso, D., E.. \& Weyganadt, J., J. (2011). Intermediate accounting, Edisi tahun 2011. Jakarta: Erlangga.

Kieso, Donald et all. (2011). Intermediate Accounting IFRS Edition. Volume 1. John Willey \& Sons Inc., United States.

Mardiasmo. 2011. "Perpajakan Edisi Revisi". Yogyakarta: Andi

PT Waskita Karya dan Entitas Anak. (2020). Laporan Keuangan Konsolidasian. Jakarta diperoleh tanggal 13 Mei 2020 dari http://www.waskita.co.id

Rizal, P Arya. 2020. Motif dan Kendala Bank Melakukan Implementasi Dini PSAK No. 71 Terhadap CKPN Kredit. Jurnal Akuntansi dan Keuangan Indonesia

Setarin, Tuty. 2020. Pengaruh LDR dan NPL Terhadap CKPN. Jurnal STIE PGRI

Sugiyono. (2016). Metode Penelitian Kuantitatif, Kualitatif dan R\&D. Bandung: PT Alfabet.

Wibowo, MP. 2020. Analisiss Penerapan PSAK 71 Dalam Penyajian Cadangan Kerugian Penurunan Nilai dan Kinerja Keuangan Perusahaan Perbankan. Jurnal Ilmiah Akuntansi Kesatuan Volume 8 Nomor 2 